\title{
Development of an in-vitro model system to investigate the mechanism of muscle protein catabolism induced by proteolysis-inducing factor
}

\author{
MCC Gomes-Marcondes', HJ Smith², JC Cooper² and MJ Tisdale*,2 \\ 'Department of Physiology and Biophysics, University of Campinas, UNICAMP, SP, Brazil 13083-970; 'Pharmaceutical Sciences Research Institute, Aston \\ University, Birmingham B4 7ET, UK
}

The mechanism of muscle protein catabolism induced by proteolysis-inducing factor, produced by cachexia-inducing murine and human tumours has been studied in vitro using $\mathrm{C}_{2} \mathrm{C}_{12}$ myoblasts and myotubes. In both myoblasts and myotubes protein degradation was enhanced by proteolysis-inducing factor after $24 \mathrm{~h}$ incubation. In myoblasts this followed a bell-shaped doseresponse curve with maximal effects at a proteolysis-inducing factor concentration between 2 and $4 \mathrm{nM}$, while in myotubes increased protein degradation was seen at all concentrations of proteolysis-inducing factor up to $10 \mathrm{nM}$, again with a maximum of $4 \mathrm{nM}$ proteolysis-inducing factor. Protein degradation induced by proteolysis-inducing factor was completely attenuated in the presence of cycloheximide $(I \mu \mathrm{M})$, suggesting a requirement for new protein synthesis. In both myoblasts and myotubes protein degradation was accompanied by an increased expression of the $\alpha$-type subunits of the 205 proteasome as well as functional activity of the proteasome, as determined by the 'chymotrypsin-like' enzyme activity. There was also an increased expression of the 195 regulatory complex as well as the ubiquitin-conjugating enzyme $\left(E 2_{14 k}\right)$, and in myotubes a decrease in myosin expression was seen with increasing concentrations of proteolysis-inducing factor. These results show that proteolysisinducing factor co-ordinately upregulates both ubiquitin conjugation and proteasome activity in both myoblasts and myotubes and may play an important role in the muscle wasting seen in cancer cachexia.

British Journal of Cancer (2002) 86, 1628 - 1633. DOl: I0.1038/sj/bjc/6600236 www.bjcancer.com

(C) 2002 Cancer Research UK

Keywords: cachexia; proteolysis-inducing factor (PIF); myotubes; ubiquitin-proteasome proteolysis

Progressive loss of lean body mass is the most debilitating and lifethreatening aspect of cancer cachexia. There may be as much as $75 \%$ loss of skeletal muscle mass while the non-muscle protein compartment is preserved (Fearon, 1992), thus distinguishing this syndrome from that of simple starvation. Muscle mass is determined by both the rate of protein synthesis and the rate of protein degradation, and alteration in the balance between these two events can lead to hypertrophy or atrophy of muscle. Thus a reduced rate of protein synthesis and an increased rate of protein degradation was found in newly diagnosed cancer patients with weight loss (Lundholm et al, 1976). In this study an increase in cathepsin D activity was found in biopsies from the rectus abdominal muscle and this correlated with the increased rate of protein degradation.

Skeletal muscle contains multiple proteolytic systems for the breakdown of proteins including lysosomal, calcium-dependent and ATP-ubiquitin-dependent proteolytic pathways (Lecker et al, 1999). However, skeletal muscle contains few lysosomes and cathepsins are not involved in the breakdown of myofibrillar proteins (Lowell et al, 1986). In addition mRNA for cathepsin B or cathepsin $B$ and $B+L$ activities were not found to change in skeletal muscle of rats implanted with a cachexia-inducing tumour (Temparis et al, 1994), although in the MAC16-induced cachexia

*Correspondence: MJ Tisdale; E-mail: M.J.Tisdale@aston.ac.uk Received 7 November 200I; revised 13 February 2002; accepted 13 February 2002 in mice there were increases in both cathepsins B and L (Lorite et al, 1998). However, the contribution of this pathway and the calcium-dependent proteolytic process to overall protein loss is small and the ATP-ubiquitin-dependent proteolytic pathway is generally considered to be mainly responsible for muscle protein catabolism in cancer cachexia.

We have been investigating the role of a sulphated glycoprotein, produced exclusively by cachexia-inducing tumours in both mouse and man, in the catabolism of skeletal muscle in cancer cachexia (Todorov et al, 1996a). Urinary excretion of the glycoprotein could be detected in patients with carcinomas of the pancreas, liver, rectum, colon, breast, lung and ovary, where the weight loss was greater than or equal to $1 \mathrm{~kg}$ per month (Cariuk et al, 1997). This material has been named proteolysis-inducing factor (PIF) because of the ability to induce muscle protein catabolism directly, both in isolated skeletal muscle (Lorite et al, 1997) and in murine myoblasts in vitro (Smith et al, 1999). Administration of PIF to non-tumour bearing mice produced a rapid decrease in body weight ( $8.6 \%$ in $24 \mathrm{~h}$ ), with specific loss of lean body mass (Lorite et al, 1998). In PIF-treated animals there was loss of skeletal muscle, while visceral protein in heart and kidney was conserved, and there was even an increase in weight of the liver. Using inhibitors of the proteolytic pathways, protein catabolism in skeletal muscle was found to be mediated entirely through an ATP-dependent pathway (Lorite et al, 1998).

Further studies in mice (Lorite et al, 2001) have shown PIF to increase both mRNA and protein levels of ubiquitin, the $M_{\mathrm{r}}$ 
14000 ubiquitin carrier protein, $\mathrm{E} 2_{14 \mathrm{k}}$, and proteasome subunits in gastrocnemius muscle, but not in heart, suggesting activation of the ATP-ubiquitin-dependent proteolytic pathway. A similar effect was seen in murine myoblasts. However, it is possible that in vivo PIF could stimulate expression of other factors, which may be responsible for the effect, while myoblasts are not the best model to study protein degradation in muscle, since they do not contain the myofibrillar proteins actin and myosin.

In order to develop an in vitro system for further mechanistic studies a comparison has been made of the effects of PIF on both murine myoblasts and myotubes, which contain myofibrillar proteins. This study examines the effect of both PIF concentration and exposure time on the activity of the ubiquitin proteasome proteolytic pathway using immunoblotting to determine the expression of $\mathrm{E} 2_{14 \mathrm{k}}, 20 \mathrm{~S}$ and $19 \mathrm{~S}$ proteasome subunits, while the functional activity of the proteasome has been determined by measuring the 'chymotrypsin-like' enzyme activity, the major proteolytic activity of the proteasome, as well as myosin expression in myotubes.

\section{MATERIALS AND METHODS}

\section{Materials}

L- $\left[2,6-{ }^{3} \mathrm{H}\right]$ Phenylalanine (sp.act. $2.00 \mathrm{TBq} \mathrm{mmol}^{-1}$ ) was purchased from Amersham International (Bucks, UK). Foetal calf serum (FCS), horse serum (HS) and Dulbecco's modified Eagle's medium (DMEM) were purchased from Life Technologies (Paisley, UK). Mouse monoclonal antibody to $20 \mathrm{~S}$ proteasome subunits $\alpha 1,2,3$, 5, 6 and 7 (clone MCP 231) was purchased from Affiniti Research Products, Exeter, UK, and mouse monoclonal antibody to myosin heavy chain was from Novocastra, Newcastle, UK. Rabbit polyclonal antisera to ubiquitin conjugating enzyme $\left(\mathrm{E} 2_{14 \mathrm{k}}\right)$ was a gift from $\mathrm{Dr}$ Simon Wing, McGill University, Montreal, Canada and rabbit polyclonal antisera to the $20 \mathrm{~S}$ proteasome $\beta$-subunit was from Calbiochem, Nottingham, UK. Mouse anti-MSSI and anti-p42 antibody were a gift from Dr Jane Arnold, UK.

\section{Cell culture}

The $\mathrm{C}_{2} \mathrm{C}_{12}$ mouse myoblast cell line was cultured in DMEM supplemented with 12\% FCS, $1 \%$ nonessential amino acids, and $1 \%$ penicillin-streptomycin, in a humidified atmosphere of $5 \%$ $\mathrm{CO}_{2}$ in air at $37^{\circ} \mathrm{C}$. Experiments were performed on cells in the subconfluent state. Myotubes were formed by allowing confluent cultures to differentiate for 9 days in DMEM containing 2\% HS with changes of medium every 2 days.

\section{Purification of PIF}

PIF was purified from solid MAC16 tumours from mice with weight loss between 20 and 25\%. The tumour homogenate was precipitated with ammonium sulphate $\left(40 \% \mathrm{w} \mathrm{v}^{-1}\right)$, and the supernatant subjected to affinity chromatography using a monoclonal antibody immobilized to a protein A matrix, as described (Todorov et al, 1996a). The immunogenic fractions were concentrated and used for studies without further purification, since the major contaminant was albumin (Todorov et al, 1996b). There was no detectable endotoxin in purified PIF preparations.

\section{Measurement of total protein degradation}

$\mathrm{C}_{2} \mathrm{C}_{12}$ myoblasts were seeded at $4 \times 10^{4}$ cells per well in $2 \mathrm{ml}$ DMEM in 6-well multidishes. After $24 \mathrm{~h}$ cells were labelled with $\mathrm{L}-\left[2,6-{ }^{3} \mathrm{H}\right]$ phenylalanine $\left(0.67 \mathrm{mCi} \mathrm{mmole}^{-1}\right)$ for a further $24 \mathrm{~h}$ period, washed three-times in PBS and incubated in fresh DMEM without phenol red $(2 \mathrm{ml})$ in the presence of various concentrations of PIF for a further $24 \mathrm{~h}$ period. The amount of radioactivity released into the medium was determined using a 2000CA Tri-Carb liquid scintillation analyzer. Protein degradation in myotubes was determined by the same method.

\section{Measurement of proteasome activity}

The chymotrypsin-like activity of the proteasome was determined fluorimetrically according to the method of Orino et al (1991), with some modifications. Cells were washed twice with ice-cold PBS and scraped from the substratum into $20 \mathrm{~mm}$ Tris $\mathrm{HCl}$, $\mathrm{pH} 7.5,2 \mathrm{~mm}$ ATP, $5 \mathrm{~mm} \mathrm{MgCl}_{2}$ and $1 \mathrm{~mm}$ dithiothreitol $(0.5 \mathrm{ml})$. The cells were dissociated by sonication with three pulses of $15 \mathrm{~s}$ with $10 \mathrm{~s}$ intervals at $4^{\circ} \mathrm{C}$. The sonicate was then centrifuged for $10 \mathrm{~min}$ at 15000 r.p.m. at $4^{\circ} \mathrm{C}$ and the resulting supernatant $(0.1 \mathrm{ml})$ was used to determine chymotrypsin-like activity using the fluorogenic substrate succinyl-LLVY-MCA $(0.1 \mathrm{mM})$ in a total volume of $0.2 \mathrm{ml}$ of $100 \mathrm{mM}$ Tris $\mathrm{HCl}$, $\mathrm{pH} 8.0$, with or without $10 \mu \mathrm{M}$ lactacystin for $1 \mathrm{~h}$ on ice. The reaction was terminated by the addition of $80 \mathrm{~mm}$ sodium acetate, $\mathrm{pH} 4.3(1 \mathrm{ml})$ and the fluorescence determined with an excitation wavelength of $360 \mathrm{~nm}$ and an emission wavelength of $460 \mathrm{~nm}$, after further dilution with $2 \mathrm{ml} 80 \mathrm{~mm}$ sodium acetate. The activity was adjusted for the protein concentration of the sample, determined using the Bradford assay (Sigma Chemical Co., Dorset, UK).

\section{Western blot analysis}

Samples of cytosolic protein $(2.5$ to $5 \mu \mathrm{g}$ ) were resolved on $12 \%$ sodium dodecylsulphate, polyacrylamide gels (SDS-PAGE) and transferred to $0.45 \mu \mathrm{m}$ nitrocellulose membranes (Hybond A, Amersham, UK), which had been blocked with 5\% Marvel in Tris buffered saline, $\mathrm{pH} 7.5$, at $4{ }^{\circ} \mathrm{C}$ overnight. The primary antibodies were used at a 1:1500 dilution, except for the 20 S proteasome $\beta$ subunit used at a 1:2000 dilution and myosin heavy chain, used at $1: 250$ dilution. The secondary antibodies were peroxidase conjugated, either goat anti-rabbit (Sigma Chemical Co., Dorset, UK) or rabbit anti-mouse (Amersham, UK) and were used at a $1: 1500$ dilution. Incubation was for $1 \mathrm{~h}$ at room temperature and development was by enhanced chemiluminescence (ECL) (Amersham, UK). Blots were scanned by a densitometer to quantitate differences, and a parallel gel was silver stained to ensure equal loading. The densitometry results were analysed using 'Phoretix ID Advanced' software.

\section{Statistical analysis}

Results were expressed as mean \pm s.e.m. Differences were determined by one-way ANOVA.

\section{RESULTS}

The effect of PIF on protein degradation in $\mathrm{C}_{2} \mathrm{C}_{12}$ myoblasts after $24 \mathrm{~h}$ incubation, as determined by the release of L- $\left[2,6-{ }^{3} \mathrm{H}\right]$ phenylalanine into the culture medium, in the presence of excess $(2 \mathrm{mM})$ phenylalanine is shown in Figure 1A. PIF enhanced protein degradation maximally at concentrations between 2.1 and $4.2 \mathrm{nM}$, with some indication of an enhanced degradation also at $16.7 \mathrm{nM}$ PIF. Protein degradation was not enhanced by PIF in the presence of cycloheximide $(1 \mu \mathrm{M})$, showing that PIF stimulation of protein degradation required new protein synthesis.

To determine whether PIF-induced protein catabolism was mediated through the ATP-ubiquitin-dependent pathway proteasome functional activity was determined by measuring 'chymotrypsinlike' enzyme activity, the major proteolytic activity of the $\beta$-subunits. Using the fluorogenic substrate succinyl LLVY-MCA an increase in enzyme activity was detectable at concentrations of PIF between 2 and 4 nM (Figure 1B). The effect on protein expression of proteasome subunits in the presence of PIF was determined 
A
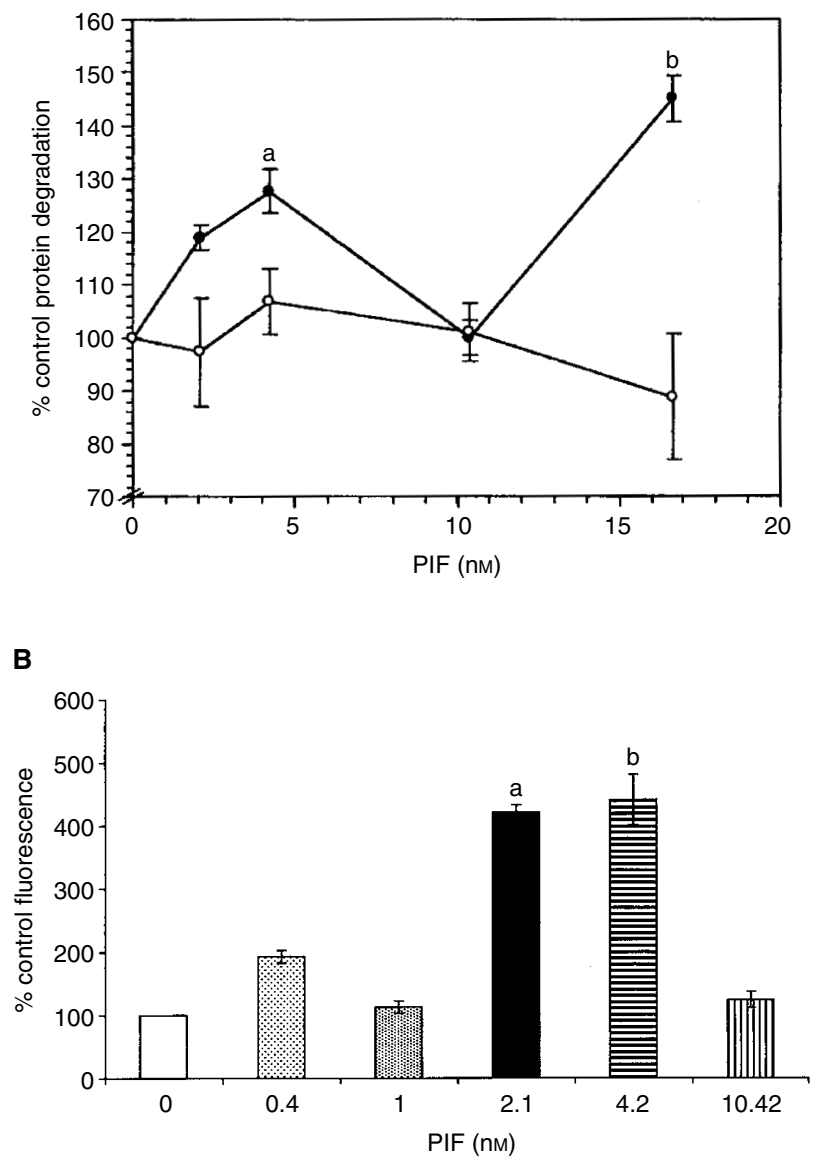

Figure I (A) Effect of PIF on total protein degradation in $\mathrm{C}_{2} \mathrm{C}_{12}$ myoblasts, either in the presence of excess phenylalanine $(2 \mathrm{mM}$ ) (solid circle) or cycloheximide ( $\mu \mathrm{M}$ ) (open circle). Measurements were made $24 \mathrm{~h}$ after the addition of PIF and are shown as mean \pm s.e.m where $n=6$. Differences from controls in the absence of PIF are indicated as $a, P<0.05$ or $b$, $P<0.01$. (B) Chymotryptic activity of soluble extracts of $C_{2} C_{12}$ myoblasts determined using the fluorogenic substrate sucLLVY-MCA after treatment with PIF for 24 h. Results are shown as mean \pm s.e.m where $n=9$.

by immunoblotting. Cellular supernatants of PIF-treated cells were Western blotted using MCP 231 antibody, a murine monoclonal to the $20 \mathrm{~S}$ proteasome, which reacts with the six different $\alpha$-type subunits. Three bands were detected at approximate molecular weight of 29000, 32000 and 35000 (Figure 2A). There was an increase in expression of all three $\alpha$-subunits in the presence of PIF, with a dose-response curve similar to that for protein degradation (Figure 1A), and with maximal induction at $4.2 \mathrm{nM}$ PIF. This effect was also attenuated in the presence of cycloheximide. The effect of $24 \mathrm{~h}$ incubation with PIF on the expression of the ATPase subunit, MSSI, of the 195 proteasome regulatory complex is shown in Figure 2B. A single band of $M_{\mathrm{r}} \sim 50000$ was apparent, which was consistent with the predicted amino acid sequence of the ATPase MS73 (Dawson et al, 1995). As with proteasome $\alpha$ subunits maximal expression was seen at concentrations of PIF between 2 and $4 \mathrm{nM}$ (500 and 300\% of the control respectively). The effect of PIF on the expression of the $M_{\mathrm{r}} 14000$ ubiquitinconjugating enzyme $\left(\mathrm{E} 2_{14 \mathrm{k}}\right)$ is shown in Figure 2C. The antibody recognises both isoforms of $\mathrm{E} 2{ }_{14 \mathrm{k}}$, including the isoform for which mRNA levels increase in atrophying muscle, as a single band at $M_{\mathrm{r}}$ 17000 (Rajapurohitam et al, 1999). PIF caused an increase in expression of $\mathrm{E} 2{ }_{14 \mathrm{k}}$ in a concentration-dependent manner, with maximal expression at 4.2 and $10 \mathrm{nM}$ (125 and $183 \%$ of control
A

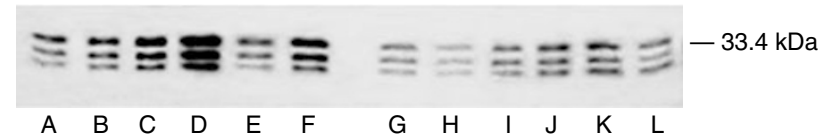

B
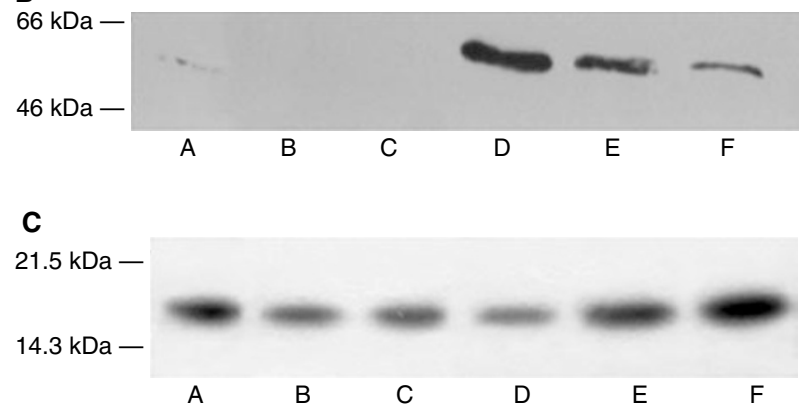

Figure 2 (A) Western blot of soluble extracts of $\mathrm{C}_{2} \mathrm{C}_{12}$ myoblasts detected with MCP23I, a murine monoclonal antibody to the proteasome $\alpha$ subunits after treatment of cells with PBS (A) or I (B), 2 (C), 4 (D), I 0.5 (E) or $17 \mathrm{nM}$ PIF (F) alone or with cycloheximide $(\mathrm{I} \mu \mathrm{M})(\mathrm{G})$ or with cycloheximide (I $\mu \mathrm{M}$ ) plus I $(\mathrm{H}), 2(\mathrm{I}), 4(\mathrm{~J}), 10.5(\mathrm{~K})$ or 17 nM PIF (L). (B) Western blot analysis of soluble extracts of $\mathrm{C}_{2} \mathrm{C}_{12}$ myoblasts either untreated $(A)$ or treated with 0.4 (B), I (C), 2 (D), 4 (E) or 10 nM PIF (F) and detected with mouse anti-human MSSI antibody. (C) Western blot analysis of soluble extracts of $C_{2} C_{12}$ myoblasts either untreated $(A)$ or treated with $0.4(B)$, I (C), 2 (D), 4 (E) or 10 nM PIF (F) and detected with E2 $14 \mathrm{k}$ rabbit polyclonal antisera.

respectively). There was evidence for an increase in expression for both proteasome $\alpha$-subunits (Figure 3A) and E2 $14 \mathrm{k}$ (Figure $3 \mathrm{~B}$ ) within only $3 \mathrm{~h}$ of PIF incubation, although at this time point lower concentrations of PIF $(0.4$ and $1 \mathrm{nM})$ were effective. This provides some evidence for co-ordinate upregulation of ubiquitin conjugating enzymes and proteasome subunits.

Further studies were carried out using $\mathrm{C}_{2} \mathrm{C}_{12}$ myotubes, since these contain the myofibrillar proteins actin and myosin, characteristic of skeletal muscle. The effect of PIF on total protein catabolism, as determined by $\left[{ }^{3} \mathrm{H}\right]$ phenylalanine release is shown in Figure 4A. Like the myoblasts there was an increased protein breakdown in the presence of PIF with a maximal effect at $4.2 \mathrm{nM}$ at $24 \mathrm{~h}$, and the effect was still apparent at 4.2 and $10 \mathrm{nM}$ PIF after $48 \mathrm{~h}$ without further addition of PIF to the culture system. The effect of PIF on proteasome proteolytic activity after $24 \mathrm{~h}$, as determined by the 'chymotrypsin-like' enzyme activity is shown in Figure 4B. A significant increase in enzyme activity was seen at all concentrations of PIF between 1 and $10 \mathrm{nM}$. There was also an increased expression of the $20 \mathrm{~S}$ proteasome $\alpha$-subunits at all concentrations of PIF between 1 and $10 \mathrm{nM}$, which increased with increasing concentrations of PIF, with a 2.6-fold enhancement at $10 \mathrm{nM}$ PIF $(P<0.01$ from control by densitometric analysis $)$ (Figure 5A). Expression of MSSI was also enhanced at all concentrations of PIF ranging between 4.6 -fold at $1 \mathrm{nM}(P<0.01$ from control) to 7.2 -fold at $10 \mathrm{nM}$ PIF $(P<0.05$ from control) (Figure $5 B)$. PIF-treatment also induced an increase in expression of $\mathrm{p} 42$, an ATPase subunit of the $19 \mathrm{~S}$ regulator that promotes ATP-dependent association of the $20 \mathrm{~S}$ proteasome with the $19 \mathrm{~S}$ regulator to form the 26S proteasome (Tanahashi et al, 1999), but there was less of a clear-cut dose-response relationship. A similar increase in expression was seen with E2 $2_{14 k}$ (Figure 5C). All concentrations of PIF above $1 \mathrm{nM}$ produced a significant $(P<0.01$ from control $)$ increase in $\mathrm{E} 2{ }_{14 \mathrm{k}}$, which with a 2.8 -fold enhancement at $10 \mathrm{nM}$ was similar to that observed with the $20 \mathrm{~S} \alpha$-subunit expression (Figure 5A). Myosin expression was reduced as the concentration of PIF increased (Figure 5D, E) in inverse proportion to activation 
A

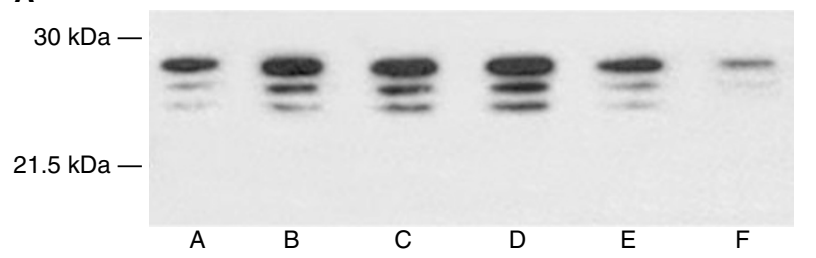

B

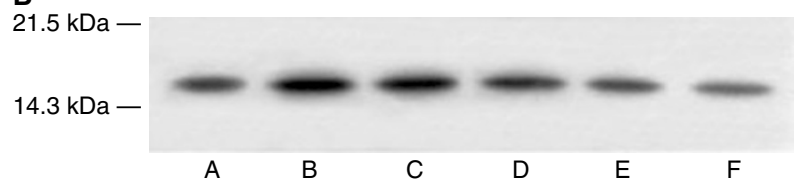

Figure 3 Western blot of soluble extracts of $C_{2} C_{12}$ myoblasts treated with PIF for $3 \mathrm{~h}$ and detected with MCP23I antibody $(\mathbf{A})$ or E2 $14 \mathrm{k}$ rabbit polyclonal antisera (B).
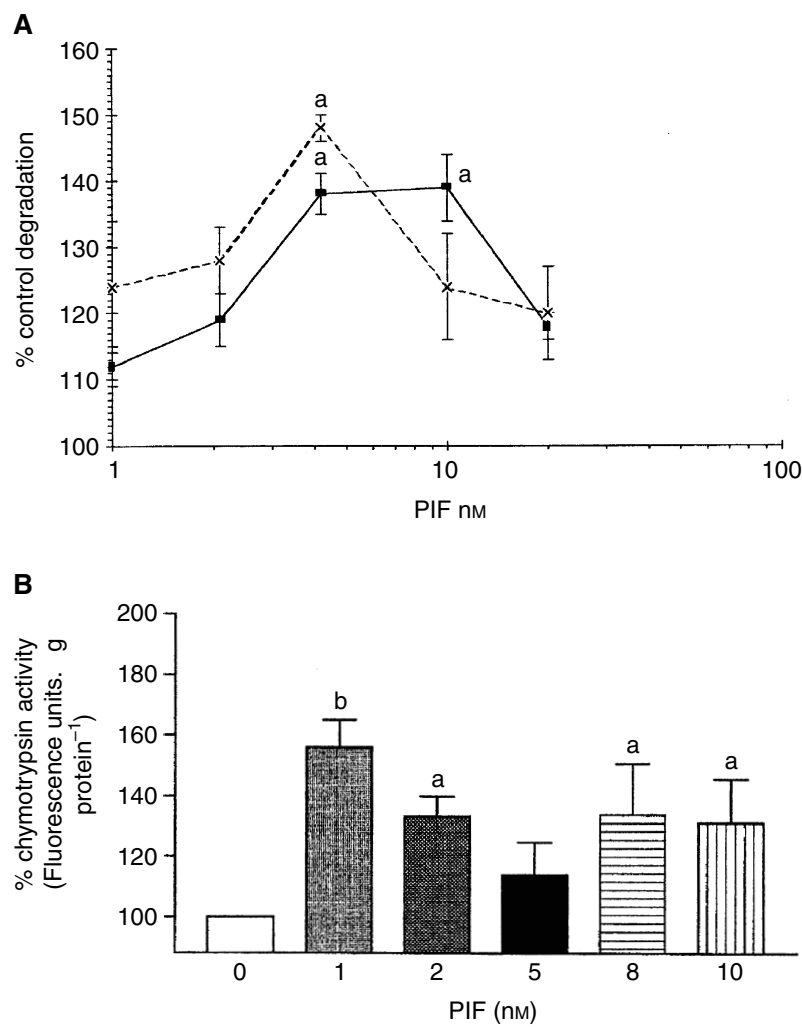

Figure 4 (A) Effect of PIF on total protein degradation in $\mathrm{C}_{2} \mathrm{C}_{12}$ myotubes after $24 \mathrm{~h}(\mathrm{x})$ and $48 \mathrm{~h}$ (solid square) incubation. Measurements were made in the presence of excess (2 mM) phenylalanine and are the average of nine determinations. Differences from controls in the absence of PIF are indicated as a, $P<0.05$ and $b, P<0.0$ I. (B) Chymotryptic activity of soluble extracts of $C_{2} C_{12}$ myotubes after treatment with PIF for $24 \mathrm{~h}$. $V$ alues shown represent mean + s.e.m where $n=8$. Differences from controls in the absence of PIF are shown as $a, P<0.05$ and $b, P<0.01$.

of expression of the $20 \mathrm{~S}$ proteasome (Figure $5 \mathrm{~A}$ ). There was still an increased expression of the proteasome, as detected by the $\beta$-subunit, $48 \mathrm{~h}$ after the original addition of PIF at concentrations of PIF between $10 \mathrm{nM}$ (three-fold) and $1 \mathrm{nM}$ (two-fold) (Figure 6A). There was also an increased expression of E2 $14 \mathrm{k}$ (1.5-fold) at these concentrations, but also an increased expression (two-fold) at $20 \mathrm{nM}$ PIF (Figure 6B). Since protein degradation was not
A

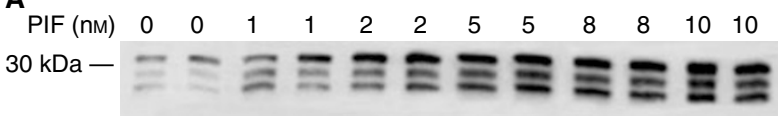

B

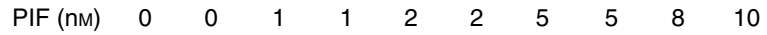

$50 \mathrm{kDa}-\cdots+\cdots+\cdots$

C

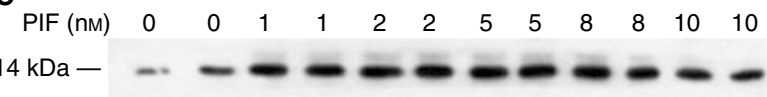

D

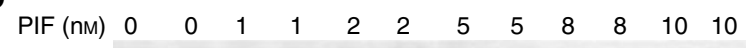
$202 \mathrm{kDa}--\cdots-\cdots-\cdots-\cdots$

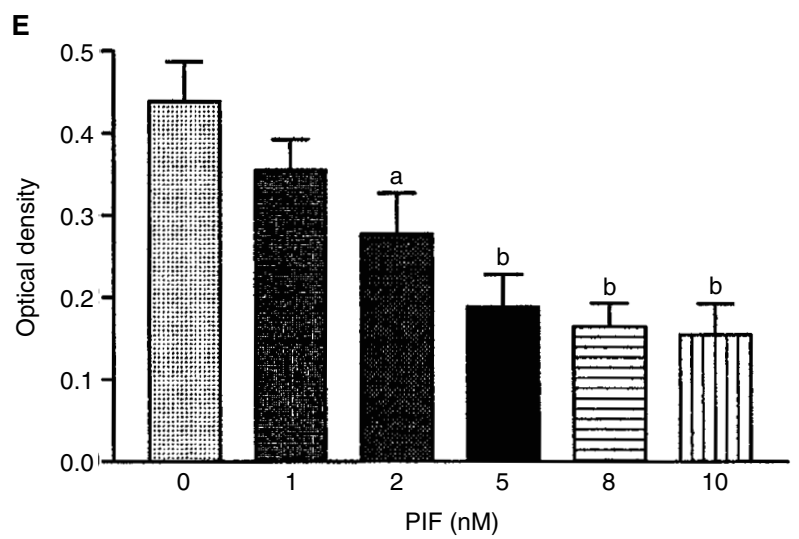

Figure 5 Western blot of soluble extracts of $\mathrm{C}_{2} \mathrm{C}_{12}$ myotubes either untreated or treated with PIF at a concentration of I, 2, 5, 8 or $10 \mathrm{nM}$ for $24 \mathrm{~h}$ and detected with either (A) MCP23I antibody directed to the proteasome $\alpha$-subunits, (B) Mouse anti-human MSSI antibody, (C) E2 14k rabbit polyclonal antiserum, or (D) Mouse monoclonal antibody directed to myosin heavy chain. (E) Shows a densitometric analysis of myosin heavy chains from four separate blots, $n=8$. Differences from control are shown as a, $P<0.05$ and $b, P<0.01$.

increased at $20 \mathrm{~nm}$ PIF (Figure 4A) this suggests that proteasome subunit induction rather than ubiquitin-conjugating enzymes are rate-limiting in protein catabolism.

\section{DISCUSSION}

The ubiquitin-proteasome system is the major pathway for selective protein degradation in eukaryotic cells, and is involved not only in protein catabolism in skeletal muscle, but numerous other processes, such as progression of the cell cycle, transcription, development, growth, and atrophy of developed tissues (Kornitzer and Ciechanover, 2000). In this process proteins are marked for degradation by attachment of a polyubiquitin chain, via the ubiquitin activating enzyme (E1), which conjugates ubiquitin through a thioester bond in an ATP-requiring reaction; a trans-esterification reaction, whereby the activated ubiquitin is transferred to a cysteine residue in the active site of the ubiquitin-conjugating enzyme (E2), suggested to be a rate-limiting step in the pathway (Wing and Banville, 1994), and a ubiquitin-protein ligase (E3), which is responsible for substrate recognition and polyubiquitination. Polyubiquitinated proteins are degraded into small peptides by a large multicatalytic protease, the $26 \mathrm{~S}$ proteasome. This pathway plays an important role in muscle protein degradation 


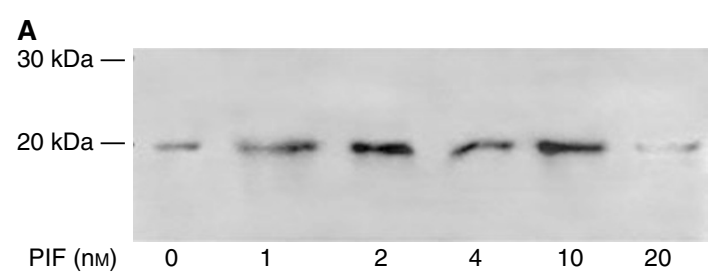

B

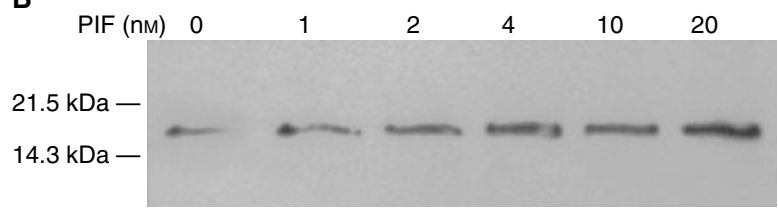

Figure 6 Western blot of soluble extracts of $\mathrm{C}_{2} \mathrm{C}_{12}$ myotubes either untreated or treated with PIF at a concentration of I, 2, 4, 10 or $20 \mathrm{nM}$ for $48 \mathrm{~h}$ and detected with either $20 \mathrm{~S}$ proteasome $\beta$-subunit rabbit polyclonal antisera $(\mathbf{A})$ or $2_{14 \mathrm{k}}$ rabbit polyclonal antisera $(\mathbf{B})$.

induced, not only in cancer cachexia (Temparis et al, 1994; Lorite et al, 1998), but also in starvation (Wing and Goldberg, 1993), sepsis (Tiao et al, 1994), metabolic acidosis (Mitch et al, 1994) and denervation atrophy (Medina et al, 1995).

Previous studies (Smith et al, 1999) have established the $\mathrm{C}_{2} \mathrm{C}_{12}$ murine myoblast cell line to be an appropriate surrogate model for studying protein degradation induced by PIF, possibly through the mediation of 15-HETE. In this study we have shown PIF to coordinately upregulate the proteasome chymotrypsin-like activity in this cell line, as well as expression of the $20 \mathrm{~S}$ proteasome $\alpha$-type subunits, MSSI, an ATPase subunit of the 19S complex and the $M_{\mathrm{r}} 14000$ E2 ubiquitin-conjugating enzyme, as determined by Western blotting. We have chosen to measure the chymotrypsinlike activity of the proteasome in view of recent observations that this is rate limiting in proteasome-dependent protein degradation (Kisselev et al, 1999). Although most studies have measured mRNA as a measure of gene expression we have measured intracellular protein levels and functional activity of the proteasome, because of reports (Kanayama et al, 1991; Shimbara et al, 1992) that in various cells elevated concentrations of mRNA of proteasome subunits were not found to be accompanied by increased concentrations or activities of proteasomes. In addition we have chosen to measure $\mathrm{E} 22_{14 \mathrm{k}}$ and $20 \mathrm{~S} / 19 \mathrm{~S}$ proteasome expression as a measure of the ubiquitin-proteasome pathway, rather than changes in ubiquitin expression and conjugation, because an increase in ubiquitin may signal an increased cell death through apoptosis (Soldatenkov and Dritschilo, 1997), rather than an increase in proteolysis. Thus, although the enhanced protein degradation in rat skeletal muscle in vivo after TNF- $\alpha$ administration is associated with an increase in gene transcription, and higher levels of free and conjugated ubiquitin (Garcia-Martinez et al, 1993), there is no evidence for an increase in proteasome expression in vitro (Ebisui et al, 1995), although an increased ubiquitin gene expression was still observed (Llovera et al, 1997). In the muscles of mice bearing the colon 26 tumour loss of muscle mass was associated with an increase in expression of both polyubiquitin and proteasome subunits. Treatment with an anti-IL-6 receptor antibody reduced polyubiquitin expression, but had no effect on expression of proteasome subunits (Tsujinaka et al, 1996).

As in a previous study (Smith et al, 1999) PIF-induced protein degradation in $\mathrm{C}_{2} \mathrm{C}_{12}$ myoblasts followed a bell-shaped doseresponse curve with maximal effects at a PIF concentration between 2 and $4 \mathrm{nM}$. In contrast there was no evidence of downregulation of protein degradation in myotubes with an increased level found above a threshold concentration of 1 nM PIF. However, the concentration of PIF required to induce protein catabolism was similar in both myoblasts and myotubes. Protein degradation induced by PIF in myoblasts was completely attenuated in the presence of cycloheximide, suggesting the requirement for new protein synthesis to affect protein catabolism. In both myoblasts and myotubes PIF induced co-ordinate upregulation of both $20 \mathrm{~S}$ proteasome $\alpha$-subunits and the $19 \mathrm{~S}$ regulator, as well as E2 $14 \mathrm{k}$. Proteasome functional activity, as determined by the 'chymotrypsin-like' enzyme activity, was also increased in both cell lines at concentrations of PIF enhancing expression of the proteasome $\alpha$ subunits, while in myotubes the expression of myosin was decreased.

This study shows co-ordinate upregulation of both the $20 \mathrm{~S}$ proteasome $\alpha$-subunits and the 19S regulator, MSSI, an ATPase, which is thought to provide energy, both for the association of the $20 \mathrm{~S}$ proteasome with the $19 \mathrm{~S}$ complex, and to inject the substrate into the proteolytic chamber of the $20 \mathrm{~S}$ proteasome. MSSI was found to be increased in the wasting muscle of rats bearing the Yoshida sarcoma (Attaix et al, 1997), and has been suggested to facilitate the rapid proteolysis of muscle proteins in cancer cachexia. Expression of MSSI has been suggested to be regulated independently of the $20 \mathrm{~S}$ proteasome subunits, since the increased expression of MSSI was normalised in cachectic rats given pentoxifylline, but not tobafylline, although both suppressed the enhanced proteolysis (Attaix et al, 1997). However, in the present study the expression of both MSSI and the 20S proteasome $\alpha$-subunits appeared to be regulated co-ordinately, suggesting central control of the whole cascade by PIF. The effect of PIF was evident within as little as $3 \mathrm{~h}$ and persisted for a $48 \mathrm{~h}$ period. However, at $48 \mathrm{~h} \mathrm{E} 2_{14 \mathrm{k}}$ expression was elevated at concentrations of PIF that had no effect on protein degradation. This suggests that ubiquitin-conjugation is not rate-limiting for proteolysis and that this requires an induced expression of proteasome subunits. This conclusion is similar to that reached by Temparis et al (1994), from a study in rats bearing the Yoshida sarcoma, where a significant reduction in protein mass was observed in the extensor digitorum longus (EDL) muscle close to the tumour, but not in the tibalis anterior (TA) muscle. An increased mRNA expression for ubiquitin, E2 $14 \mathrm{k}$ and the proteasome subunits $\mathrm{C} 8$ and $\mathrm{C} 9$ was found in the EDL muscle, but not in the TA muscle, where only mRNA for ubiquitin and E2 $14 \mathrm{k}$ was increased. This suggested that increased mRNA expression for ubiquitin and E2 $14 \mathrm{k}$ came first, but that increased gene expression of proteasome subunits was essential for enhanced protein catabolism. This conclusion is also supported from studies of skeletal muscle during cancer cachexia where an elevation of the high molecular mass conjugates of ubiquitin is observed (Lorite et al, 1998), suggesting that this step is not rate limiting in proteolysis. Thus proteasome catalytic activity rather than substrate ubiquitination appear to be the rate-limiting step in protein catabolism.

Further studies will concentrate on the mechanism by which PIF leads to upregulation of the ubiquitin-proteasome pathway and inhibitors of this process.

\section{ACKNOWLEDGEMENTS}

This work has been supported by the Association for International Cancer Research (AICR). Dr Gomes-Marcondes was supported by a postdoctoral programme sponsored by FAPESP, São Paulo, Brazil, Grant Number 99/0370-3. Dr Alison Whitehouse for assistance with the Western blots. 


\section{REFERENCES}

Attaix D, Taillandier D, Combaret L, Ralliere C, Larbaud D, Aurousseau E, Tanaka K (1997) Expression of subunits of the 19S complex and of the PA28 activator in rat skeletal muscle. Mol Biol Rep 24: 95-98

Cariuk P, Lorite MJ, Todorov PT, Field WN, Wigmore SJ, Tisdale MJ (1997) Induction of cachexia in mice by a product isolated from the urine of cachectic cancer patients. Br J Cancer 76: 606-613

Dawson SP, Arnold JE, Mayer NJ, Reynolds SE, Billett MA, Gordan C, Collenux L, Kloetzel PM, Tanaka K, Mayer RJ (1995) Developmental changes of the $26 \mathrm{~S}$ proteasome in abdominal intersegmental muscles of Manduca sexta during programmed cell death. J Biol Chem 270: 1850-1858

Ebisui C, Tsujinaka T, Morimoto T, Kan K, Iijama S, Yano M, Kominami E, Tanaka K, Moden M (1995) Interleukin-6 induces proteolysis by activating intracellular proteases (cathepsins $\mathrm{B}$ and $\mathrm{L}$, proteasome) in $\mathrm{C}_{2} \mathrm{C}_{12}$ myotubes. Clin Sci 89: 431-439

Fearon KCH (1992) The mechanisms and treatment of weight loss in cancer. Proc Nut Soc 51: 251-265

Garcia-Martinez C, Lopez-Soriano FJ, Argilles JM (1993) Acute treatment with tumor necrosis factor $\alpha$ induces changes in protein metabolism in rat skeletal muscle. Mol Cell Biochem 125: 11-18

Kanayama H, Tanaka K, Aki M, Kagawa S, Miyaji H, Satoh M, Okada F, Sato S, Shimbara N, Ichihara A (1991) Changes in expressions of proteasome and ubiquitin genes in human renal cancer cells. Cancer Res 51: $6677-$ 6685

Kisselev F, Akopian TN, Castillo V, Goldberg AL (1999) Proteasome active sites allosterically regulate each other, suggesting a cyclical bite-chew mechanism for protein breakdown. Mol Cell 4: 359-402

Kornitzer D, Ciechanover A (2000) Modes of regulation of ubiquitinmediated protein degradation. J Cell Physiol 182: $1-11$

Lecker SH, Solomon V, Mitch WE, Goldberg AL (1999) Muscle protein breakdown and the critical role of the ubiquitin-proteasome pathway in normal and disease states. J Nutr 129: 227S - 237S

Llovera M, Garcia-Martinez C, Agell N, Lopez-Soriano FJ, Argilés JM (1997) TNF can directly induce the expression of ubiquitin-dependent proteolytic system in rat soleus muscles. Biochem Biophys Res Commun 230: 238-241

Lorite MJ, Cariuk P, Tisdale MJ (1997) Induction of muscle protein degradation by a tumour factor. Br J Cancer 76: $1035-1040$

Lorite MJ, Thompson MG, Drake JL, Carling G, Tisdale MJ (1998) Mechanism of muscle protein degradation induced by a cancer cachectic factor. $\mathrm{Br}$ J Cancer 78: $850-856$

Lorite MJ, Smith HJ, Arnold JA, Morris A, Thompson MG, Tisdale MJ (2001) Activation of ATP-ubiquitin-dependent proteolysis in skeletal muscle in vivo and murine myoblasts in vitro by a proteolysis-inducing factor (PIF). Br J Cancer 85: 297-302

Lowell BB, Ruderman NB, Goodman MN (1986) Evidence that lysosomes are not involved in the degradation of myofibrillar proteins in rat skeletal muscle. Biochem J 234: $237-240$

Lundholm K, Bylund AC, Holm J, Schersten T (1976) Skeletal muscle metabolism in patients with malignant tumor. Eur J Cancer 12: 465-473

Medina R, Wing SS, Goldberg AL (1995) Increases in levels of polyubiquitin and proteasome mRNA in skeletal muscle during starvation and denervation atrophy. Biochem J 307: 631-637
Mitch WE, Medina R, Grieber S, May RC, England BK, Price SR, Bailey J, Goldberg AL (1994) Metabolic acidosis stimulates muscle protein degradation by activating the adenosine triphosphate-dependent pathway involving ubiquitin and proteasomes. J Clin Invest 93: 2127-2133

Orino E, Tanaka K, Tamura T, Sone S, Ogura T, Ichihara A (1991) ATPdependent reversible association of proteasomes with multiple protein components to form $26 \mathrm{~S}$ complexes that degrade ubiquitinated proteins in human HL-60 cells. FEBS Lett 284: 206-210

Rajapurohitam V, Morales CR, El-Alfy M, Lefrancois S, Beadard N, Wing SS (1999) Activation of a UBC4-dependent pathway of ubiquitin conjugation during postnatal development of the rat testis. Dev Biol 212: 217-228

Shimbara N, Orino E, Sone S, Ogura T, Takashina M, Shono M, Tamura T, Yasuda H, Tanaka K, Ichihara A (1992) Regulation of gene expression of proteasomes (multi-protease complexes) during growth and differentiation of human hematopoietic cells. J Biol Chem 267: 18100-18109

Smith HJ, Lorite MJ, Tisdale MJ (1999) Effect of a cancer cachectic factor on protein synthesis/degradation in murine $\mathrm{C}_{2} \mathrm{C}_{12}$ myoblasts: Modulation by eicosapentaenoic acid. Cancer Res 59: 5507-5513

Soldatenkov VA, Dritschilo A (1997) Apoptosis of Ewing's sarcoma cells is accompanied by accumulation of ubiquitinated proteins. Cancer Res 57: $3881-3885$

Temparis S, Asensi M, Taillandier D, Aurousseau E, Larbaud D, Obled A, Becket D, Ferrara M, Estrela JM, Attaix D (1994) Increased ATP-ubiquitin-dependent proteolysis in skeletal muscles of tumor-bearing rats. Cancer Res 54: $5568-5573$

Tanahashi N, Kawshara H, Murakami Y, Tanaka K (1999) The proteasomedependent proteolytic system. Mol Biol Rep 26: 3-9

Tiao G, Fagan JM, Sammuels N, James JH, Hudson K, Lieberman M, Fischer JE, Hasselgren P-O (1994) Sepsis stimulates non-lysosomal, energy-dependent proteolysis and increases ubiquitin mRNA levels in rat skeletal muscle. J Clin Invest 94: 2255-2264

Todorov P, Cariuk P, McDevitt T, Coles B, Fearon K, Tisdale M (1996a) Characterization of a cancer cachectic factor. Nature 379: 739-742

Todorov PT, McDevitt TM, Cariuk P, Coles B, Deacon M, Tisdale MJ (1996b) Induction of muscle protein degradation and weight loss by a tumor product. Cancer Res 56: $1256-1261$

Tsujinaka T, Fujita J, Ebisui C, Yano M, Kominami E, Suzuki K, Tanaka K, Katsume A, Ohsugi Y, Shiosaka H, Mondem M (1996) Interleukin-6 receptor antibody inhibits muscle atrophy and modulates proteolytic systems in interleukin 6 transgenic mice. J Clin Invest 97: 244-249

Wing SS, Goldberg AL (1993) Glucocorticoids activate the ATP-ubiquitindependent proteolytic system in skeletal muscle during fasting. Am J Physiol 264: E668-E676

Wing SS, Banville D (1994) 14-kDa Ubiquitin-conjugating enzyme. Structure of the rat gene and regulation upon fasting and by insulin. Am J Physiol 267: $\mathrm{E} 39-\mathrm{E} 48$ 